\title{
Can Online Transparency Improve Accountability? The Case of Portuguese Private Social Solidarity Institutions
}

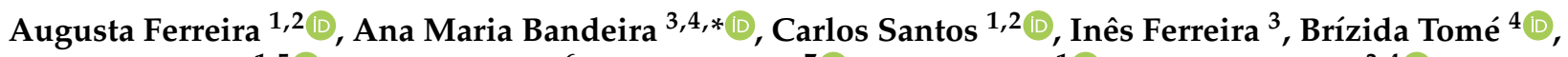 \\ Alberto J. Costa ${ }^{1,5} \oplus^{\infty}$, Carla Joaquim ${ }^{6}$, Cristina Góis ${ }^{7}\left(\mathbb{D}\right.$, Denise Curi ${ }^{1}{ }^{(D}$, Deolinda Meira ${ }^{3,4}(\mathbb{D}$, \\ Graça Azevedo ${ }^{1,2}{ }^{\circledR}$, Helena Inácio ${ }^{1,5}{ }^{\oplus}$, Mafalda Jesus ${ }^{8}$, Maria Goreti Teixeira ${ }^{8}$, Patrícia Monteiro ${ }^{8}$, \\ Rúben Duarte ${ }^{1}$ and Rui Pedro Marques ${ }^{1}$
}

Citation: Ferreira, A.; Bandeira, A.M.; Santos, C.; Ferreira, I.; Tomé, B.;

Costa, A.J.; Joaquim, C.; Góis, C.;

Curi, D.; Meira, D.; et al. Can Online

Transparency Improve

Accountability? The Case of

Portuguese Private Social Solidarity

Institutions. Sustainability 2022, 14,

1632. https://doi.org/10.3390/

su14031632

Academic Editor:

Jennifer Martínez-Ferrero

Received: 19 December 2021

Accepted: 27 January 2022

Published: 30 January 2022

Publisher's Note: MDPI stays neutral with regard to jurisdictional claims in published maps and institutional affiliations.

Copyright: (c) 2022 by the authors. Licensee MDPI, Basel, Switzerland. This article is an open access article distributed under the terms and conditions of the Creative Commons Attribution (CC BY) license (https:// creativecommons.org/licenses/by/ $4.0 /)$.
1 Higher Institute of Accounting and Administration of University of Aveiro, University of Aveiro, 3810-193 Aveiro, Portugal; augusta.ferreira@ua.pt (A.F.); carlos.santos@ua.pt (C.S.); alberto.costa@ua.pt (A.J.C.); denpec11@gmail.com (D.C.); graca.azevedo@ua.pt (G.A.); helena.inacio@ua.pt (H.I.); rubenduarte@ua.pt (R.D.); ruimarques@ua.pt (R.P.M.)

2 Center for Research in Accounting and Taxation, Polytechnic Institute of Cávado and Ave, 4750-810 Barcelos, Portugal

3 Porto Accounting and Business School, Polytechnic of Porto, 4200-465 Porto, Portugal; inesaferreira98@gmail.com (I.F.); meira@iscap.ipp.pt (D.M.)

4 Centre for Social and Organizational Studies of Polytechnic of Porto, 4200-465 Porto, Portugal; brizida.tome@gmail.com

5 GOVCOPP_Research Unit on Governance, Competitiveness and Public Policies, University of Aveiro, 3810-193 Aveiro, Portugal

6 Department of Economics, Management, Industrial Engineering and Tourism, University of Aveiro, 3810-193 Aveiro, Portugal; carlamfreitas@live.ua.pt

7 Coimbra Business School Research Centre ISCAC, Polytechnic Institute of Coimbra, 3045-093 Coimbra, Portugal; cgois@iscac.pt

8 Confederação Nacional das Instituições de Solidariedade, 4050-492 Porto, Portugal; mj.tecnico@cnis.pt (M.J.); maria.goreti.teixeira.1@gmail.com (M.G.T.); pm.tecnico@cnis.pt (P.M.)

* Correspondence: bandeira@iscap.ipp.pt

\begin{abstract}
The development of the non-profit sector (NPS) in Portugal has been gaining relevance in recent times, particularly in the form of institutions whose purpose is to broaden and increase the response to the needs of the most needy and socially vulnerable citizens. The financing of Portuguese non-profit sector entities is essentially made up of income from their activity, donations and public or governmental support. Therefore, these entities face increasing pressure from their funders, users and citizens in general for a greater dissemination of good practices regarding the social impact they have on the community; in particular, they are increasingly required to be transparent in their activities. The main objective of this study was to analyse the level of accountability and transparency of the private social solidarity institutions (IPSS) of the municipality of Porto. To this end, the websites of these institutions were analysed, using a qualitative and quantitative methodology, using the application of the transparency index Enhancement of an Accountability Guide for Learning E-Government. This analysis allowed us to verify that there are still a considerable number of entities that do not have an institutional website, and those that do, have a low level of transparency.
\end{abstract}

Keywords: social economy; private institution of social solidarity; transparency; accountability

\section{Introduction}

Increasing globalisation, the economic crisis and the ageing population are some of the reasons why it is difficult for the State to meet all social needs (Ferreira et al., 2016) [1]. In Portugal, in recent times, there has been a massive development of NPS, namely in the form of institutions that contribute to the generation of a greater social offering (Bandeira et al., 2020) [2]. Since a large part of the funding of these institutions is made 
up of subsidies financed by the Government, these entities face pressure for greater accountability from their funders, users and citizens in general and a growing need to disclose good practices and the social impact they have on the community, that is, pressure to be guided by greater transparency. This led to the creation of the TFA project"TheoFrameAccountability-Theoretical framework for promotion of accountability in the social economy sector: the IPSS case" ("TheoFrameAccountability-Theoretical framework for promotion of accountability in the social economy sector: the IPSS case" is a project financed by FEDER-European Regional Development Fund through COMPETE 2020-Competitiveness and Internationalization Operational Program (POCI) and by national funds through FCT-Foundation for Science and Technology, with the reference POCI-01-0145-FEDER-030074, promoted by the University of Aveiro and with the participation of the National Confederation of Solidarity Institutions, the Polytechnic Institute of Coimbra and the Polytechnic Institute of Porto (https://www.tfa.pt/) accessed on 14 December 2021.

The assessment of the transparency of institutions has been constituting a line of investigation as a result of the concern of academics and practitioners with the objective of contributing to the improvement of transparency practices and the increase in the institutions' accountability. Thus, the main objective of the present study is to evaluate the level of transparency of the IPSS and in this sense, the following research problem was posed: what is the level of transparency of the IPSS?

One way to assess transparency is through the institutional website —online transparency—and, in this line, there are different indices in the literature (see Santos et al., 2018) [3].

In order to answer the research problem, it was decided to adapt the EAGLE index, in which the following various dimensions will be analysed: (i) whether it is common practice for IPSS to adopt an institutional website; (ii) the quality of IPSS institutional websites; (iii) the level of disclosure of financial, budgetary and performance information on the IPSS websites; (iv) the level of maturity of the online services available on the IPSS websites.

The methodology adopted is qualitative with regard to the analysis of the sites and data collection for the EAGLE index and quantitative (descriptive statistics) for the analysis of the results.

The results obtained show that the average level of transparency of the IPSS of the municipality of Porto is around 34\%, which determines low transparency. Therefore, the expected results were not achieved, i.e., institutions did not follow technological evolution and also did not take advantage of the opportunity that the current pandemic situation provided them for the technological transition of their services.

The remaining work is organised as follows: Section 2 reviews the literature and, considering the identified gaps, defines the objective, the problem and the research questions. Section 3 describes the methodology. Section 4 presents the results and proceeds with their analysis and discussion. Section 5 presents the final considerations, the limitations of the study and the proposals for future research.

\section{Literature Review}

The term "Social Economy" first appeared in Europe-more specifically in France-in the 19th century (Barros 2015 [4], Bandeira et al., 2020 [2]). Franco (2008) [5] Barros (2015) [4] and Bandeira et al. (2020) [2] attribute the authorship of this expression to Charles Gide (1847-1932), according to whom this sector is like a branch of economic science that brings together three movements - cooperative, mutualist and associative-originating from civil society, which aim to imbue the living conditions of the population with initiatives of solidarity and redistributive action of State resources.

The social enterprises that are part of the scope of the social economy sector are diverse as we will present below. 


\subsection{Social Economy in Portugal}

The Portuguese Basic Law of the Social Economy (LBES), law No. 30/8 May 2013 [6] (Law No. 30/8 May 2013, consultation at https:/ / www.casadaimprensa.pt/GetFile.ashx? FileID $=26$ accessed on 30 November 2021), establishes the general principles of the legal framework of the social economy, as well as the measures to encourage its activity according to its own principles and purposes. Under this law, the social economy is described as the set of economic-social activities with the purpose of making the general interests of society prevail, either directly or through the pursuit of the interests of its members, users and beneficiaries, freely carried out by the following entities: cooperatives; mutualist associations; misericórdia; foundations; IPSS; associations with altruistic purposes acting in the cultural, recreational, sports and local development fields; entities covered by the community and self-management subsectors, integrated under the terms of the Constitution into the cooperative and social sector; other entities provided with legal personality, which respect the guiding principles of the social economy and which are listed in its database.

According to Meira (2013) [7], one of the primary objectives of LBES is to promote, stimulate and develop the social economy and its organisations. Thus, nr.2 of article 10 of LBES states that the public authorities, within the scope of their competences regarding policies to encourage the social economy, must do the following: promote the principles and values of the social economy; foster the creation of mechanisms to reinforce the economic and financial self-sustainability of social economy entities; facilitate the creation of new social economy entities and support the diversity of initiatives that are characteristic of this sector; encourage research, innovation, professional training and support the access of social organisations to technological innovation and organisational management processes; deepen the dialogue between public bodies and representatives of the social economy at national and European Union level, thus promoting mutual knowledge and the dissemination of good practices.

The LBES, in its 5th article, defines that social economy entities act in accordance with the following guiding principles: people-centred priority and social objectives; free and voluntary membership and participation; democratic control of their respective bodies by their members; conciliation between the interests of members, users or beneficiaries and the general interest; respect for the values of solidarity, equality and non-discrimination, social cohesion, justice and equity, transparency, shared individual and social responsibility and subsidiarity; autonomous and independent management from public authorities and any other entities outside the social economy; allocation of surpluses to the pursuit of sustainable development objectives, services to members' interest or of general interest.

The non-profit sector entities (ESNL), mostly of a private nature, seek the satisfaction of an end, providing their members with a provision of services or a supply of goods for a non-profit purpose. Thus, they exist to serve society in general by providing goods, services and ideas to improve the quality of life in society, never aiming to remunerate the holders and sponsors (Antão et al., 2012 [8]). They seek to mitigate the gaps in the public sector and be an alternative to private initiative (Bandeira, 2013 [9], Bandeira 2016 [10], Vieira, 2015 [11] and Vieira, 2017 [12]).

To play their role effectively, transparency and good governance practices are of great value for the survival of these organisations, as argued by Moreno-Albarracín et al. (2020). Indeed, the growth of ESNL, their importance and weight in the economy justify the strengthening of requirements regarding the transparency of the activities they carry out and the resources used (Burger and Owens, 2010 [13]; Rodríguez et al., 2012 [14]; Striebing, 2017 [15]; Cabedo et al., 2018 [16]; Dumont, 2013 [17]). These requirements include the obligation to provide reliable information about the management of the resources entrusted to them and the results achieved in the development of their activities (Antão et al., 2012 [8]; Hyndman and McConville, 2016 [18]; Sanzo-Pérez et al., 2017 [19]).

According to Amado (2007), ESNL differ from other entities in the fact that their main objective is to meet social needs and combat social exclusion. These organisations end up being dynamizing agents of local development as well as a stimulus to participation and 
job creation. In financial terms, the profits or financial surpluses resulting from the activity are reinvested in the organisation itself, with no profits being distributed to the associates (Moreno-Albarracín et al., 2020).

In line with Carvalho (2007) [20], the ESNL have three distinctive characteristics in relation to for-profit entities. The first refers to the fact that the financing of their activity results from their own assets or from resources attributed by natural or legal persons, without these attributed resources being subject or conditioned to consideration derived from the obtaining of benefits. The second refers to the purposes of general interest that transcend the productive activity and the sale of products or provision of services. The third refers to the absence of any participation by its holders, which may be purchased, ceded, exchanged or from which some type of economic counter payment is expected, even in the event of the entity ceasing its activities and being subject to liquidation.

In short, these entities are generally characterized by the following: having a formal and institutional existence, i.e., legal personality; not being exclusively for-profit; not distributing profits; being independent from public authorities in their management; developing activities aimed at the public good; being private entities with organized formal structures; being voluntary or involving a high degree of volunteerism, and performance evaluation is generally complex and difficult (e.g., Moreno-Albarracín et al., 2020 [21]; and Salamon and Sokolowski, 2016 [22]).

The best-known examples of Portuguese ESNL are associations, mutualist associations, foundations, cooperatives, misericórdia and IPSS. Associations are organisations formed by a group of people, with or without a legal personality, to achieve a common objective (Gomes and Pires, 2014) [23]. Associates are not bound to reciprocal rights and obligations but rather to rules established by them, so that they may share the advantages of cooperation and the set of objectives and aspirations presented by the various members. Gomes and Pires (2014) [23] also state that associativism is differentiated by its normally voluntary nature, by the meeting of two or more individuals and by its use as an instrument to satisfy individual human needs. In turn, mutualist associations are institutions with an unlimited number of members, undetermined capital and undefined duration which, essentially through their members' contributions, practice mutual aid purposes in the interest of these and their families (Andrade and Franco, 2007 [24]). Foundations have their own assets and are based on a perpetual bond established by the founder. They are autonomous long-term projects, and their main difficulty is the acquisition of resources. To this end, they resort to the exercise of lucrative activities which finance the purpose of the foundation (Domingues, 2016 [25]). The cooperatives are autonomous collective persons united voluntarily who, through the cooperation and mutual aid of their members, aim to satisfy their common needs and aspirations through a common, democratically controlled organisation (Meira, 2009) [26]. The misericórdia are organisations linked to the Catholic Church that are among the most anti-profit organisations in Portugal. They constitute institutions that are part of the canonical juridical order that aim to satisfy social needs and practice acts of Catholic cult (Teixeira, 2014) [27].

IPSS are collective, non-profit entities, established on the initiative of private individuals, in order to give organized expression to the moral duty of justice and solidarity, contributing to the effectiveness of citizens' social rights, provided they are not administered by the State or other public body (Decree-Law No. 172-A/14) [28] (Decree-Law No. 172-A/14 consulted at https://dre.pt/dre/legislacao-consolidada/decreto-lei/2014-69878914 accessed on 2 December 2021 ).

As we have seen and is emphasized, for example, by Teasdale (2012) [29], there is a wide variety of types of organisations within the social economy sector. This is due to the fact that "social enterprise" is a fluid and tested concept, constructed by different actors who promote different discourses linked to different forms of organisation. We cannot also fail to reiterate that there are entities that have a strong awareness of social and environmental behaviour (e.g., Yunus et al., 2021) [30]. 


\subsection{Transparency and Accountability of IPSS}

\subsubsection{Concept of Transparency}

According to Armstrong (2005) [31], the concepts of integrity, transparency and accountability were identified by the United Nations as an integral part of the founding principles of public administration. Integrity refers to honesty or reliability in the performance of official duties, serving as an antithesis to corruption or abuse of power. Transparency refers to unrestricted public access to prompt and reliable information on decision making and performance in the public sector. Accountability refers to the obligation, on the part of public officials, to report on the use of public resources and responsibility for failure to meet stated performance objectives. The author argues that these three concepts are mutually dependent.

Fox (2007) [32] divides the concept of transparency into clear and opaque. Opaque or diffuse transparency involves the dispersal of information that does not reveal how institutions actually behave in practice, whether in terms of decision making, or in terms of the results of their actions. This term also refers to information that is only disclosed by name or disclosed but not reliable. Clear transparency, on the other hand, refers to information access policies and programmes that reveal reliable information on institutional performance, specifying the responsibilities of officials and the destination of public resources. This type of transparency highlights institutional behaviour, which allows stakeholders to seek constructive change strategies. The author, in turn, states that transparency is far from generating accountability.

Lee and Joseph (2013) [33] argue that organisational transparency consists of two dimensions, performance and financial transparency. These dimensions refer to the level of accessibility with which donors, beneficiaries and the general public may access information as to how efficient a non-profit organisation might be and how efficient it might be in fulfilling its social mission.

\subsubsection{Transparency in ESNL}

Ortega-Rodríguez, Licerán-Gutiérrez and Moreno-Albarracín (2020) [21] define transparency in ESNL as the moral practice of accountability whereby organisations have to disclose information about the activities they carry out and the resources they use to achieve their social purpose. They also argue that the requirement for high levels of transparency for these entities is based on two fundamental pillars. On the one hand, public entities are the main stakeholders of ESNLs, which leads them to assume the act of disclosing financial and non-financial information in a clear and transparent way as a counterpart for the financial support of public funds. On the other hand, inappropriate or fraudulent practices by an ESNL cause serious damage to the image of these institutions, putting at risk future public financing.

Saxton and Guo (2011) [34] conducted a study of 117 US community foundation websites, from which they collected financial and non-financial data, and concluded that the website has been used more effectively to provide financial and performance information than to provide dialogue mechanisms for stakeholder input and interactive engagement. The authors also highlight capacity and governance-related variables, especially asset size and board performance, as the most significant factors associated with the adoption of webbased accountability practices. For example, Hale (2013) [35] confers for the importance of transparency in as much as the ability of external stakeholders to access organisationspecific information concerning the functioning of a non-profit organisation is important for donation decisions, an important source of financing for these entities. It can be said that there is a consensus view that transparency has become a factor of high strategic value for an ESNL to ensure its own survival (e.g., Moreno-Albarracín et al., 2021 [36]; Behn (2010) [37]).

In conclusion, the concept of transparency is the process of disclosure, by the entities, of relevant information for their evaluation. The information should be of an economicfinancial, social and political nature and have a set of relevant characteristics, such as timely, 
reliable and accessible to all interested parties. For example, an entity should disclose on its institutional website relevant information regarding the goods and/or services provided, such as the activities developed, the prices practiced and opening hours. Transparency refers to the availability of timely, reliable and easy-to-interpret information on the entity's performance and decision making. Transparency is a symbol for accountability and a critically important dimension of nonprofit organisations (Hale, 2013) [35].

\subsubsection{Transparency and Accountability in the IPSS: The Portuguese Case}

Accountability is a multidimensional concept that includes providing information, in a transparent manner, enabling stakeholder participation, evaluating performance, and responding to stakeholder concerns (e.g., Tremblay-Boire and Prakash, 2015 [28]; Baur and Schmitz, 2012 [38]).

In order to analyse the presence of Portuguese IPSS on the Internet in the sense of, in this way, seeking to analyse the respective transparency and accountability, Ferreira et al. (2016) [1], three months before the beginning of the obligation foreseen in Decree-Law 172-A/2014 [39], created a maturity index considering a set of minimum indicators classified by dimensions. This index consists of the following six dimensions: general information, financial information, content updating, accessibility, navigability and facilities for citizens with special needs. The authors concluded that only about $37.62 \%$ of the 420 IPSS analysed had a website. Although some of the IPSS that had a website already disclosed financial information, these authors obtained evidence that the content provided on IPSS websites did not meet the minimum indicators selected in the index used. The updating of its content, accessibility, navigability and ease of access for citizens with special needs, also did not meet the minimum requirements considered in this index. It can therefore be stated that, in 2016, most IPSS did not have a website, and those that did, did not always meet the minimum requirements, thus limiting compliance with the aforementioned obligation.

Motivated by the previous research, in 2019, the same authors, conducted a new study with data from 2017 (Ferreira et al., 2019) [40]. Although the new results show an improvement in the maturity index, the findings expose that the websites still did not fully match the desired maturity level requirements. That is, although the web presence was approximately the same as in the previous study (about 37.86\%), the new results revealed an improvement.

Similarly, but for a more specific territory than Ferreira et al. (2016 [1], 2019 [40]), Bandeira et al. (2020) [2] analysed a set of IPSS in the Autonomous Region of Madeira to assess the level of transparency regarding the disclosure of economic and financial information. The results obtained showed that $71 \%$ of the institutions have their own institutional website and that only $57 \%$ of these entities disclosed accounts for the financial year. Thus, although also in this specific territory there is a high rate of non-compliance with the obligation to publish accounts in relation to Decree-Law 172-A/2014, the results are nevertheless better than in the national total. This work, combined with the previous ones, has the ability to show that there is territorial variability.

Additionally, of more specific territorial scope than Ferreira et al. (2016 [1], 2019 [40]), Pardal et al. (2019) [41] conducted a study in which they evaluated how the IPSS in Setubal County use the Internet to disclose the Institution and, in particular, disclose financial and non-financial information. Based on the elaboration of an index with several dimensions (institutional-relating to general information about the institution; activities or projectsrelating to projects developed or in progress; financial-financial in nature, which unfolds in an accrual basis and cash basis; navigability—relating to the policy of the website itself; design/accessibility-focusing on aspects of structure, images and contacts). The authors concluded that (i) only $47 \%$ of the IPSS in the municipality of Setúbal have their own institutional site, and (ii) $21 \%$ have their site hosted on a domain other than that of the institution itself. They concluded that the degree of disclosure of financial information presented a degree of disclosure of $24 \%$. The territorial variability in the disclosure of 
financial information is confirmed, so "the IPSS in the municipality of Setubal still has a long way to go towards greater transparency and accountability" (Pardal et al., 2019, p. 18 [41]).

Our study analysed the websites of a sample of entities from the municipality of Porto. Hence, our analysis is territorially more limited than Ferreira et al. (2016 [1], 2019 [40]), although it follows the methodology of these authors, and is more aligned with Pardal et al. (2019) [41] and Bandeira et al. (2020) [2]. It cannot be generalized to the whole territory and the reader should be aware of this fact.

In turn, for entities more specific than those considered in the previous studies, Tomé et al. (2016) [42] developed a work on the main challenges faced by social solidarity cooperatives in relation to accountability and, consequently, transparency in light of Decree-Law 172-A/2014. They concluded that, of this type of entities, the results were even worse as $83 \%$ did not perform any type of disclosure, $15 \%$ disclosed account reports and only $2 \%$ used the management report as a disclosure tool.

According to the existing literature for Portugal on the subject, it is also worth mentioning the work Silva et al. (2018) [43]. These authors attended to the transparency procedures in the provision of accounts, discussing the problematic of the existence of a transparent management of resources and the provision of information between these entities and the State in the accounting and fiscal scope. However, they restricted the analysis to the specific and limited study of the case of one association. Although the entity did not present all the mandatory financial statements, the authors found the existence of concern in presenting information in order to ensure the confidence of its stakeholders.

In short, we can conclude that there is still great difficulty in disclosing financial and non-financial information by social economy entities, primarily because many of them do not yet have an institutional website. Therefore, many ESNL are not complying with the obligation required by Decree-Law 172-A/2014 [39].

In any case, it should also be noted that, in this disclosure process, there is no consensus on the best way to analyse and measure transparency, and it is necessary to develop models that allow, on the one hand, to quantify the respective level required and, on the other hand, to determine the criteria used to qualify an organisation as more or less transparent (e.g., Ortega-Rodríguez et al., 2020 [44] and Lee et al., 2013 [33]).

\section{Methodology}

In view of the literature review and the identified gaps, the main objective of the present study is to assess the level of transparency of the IPSS. In order to achieve this objective, the following research problem was identified and stated: what is the level of transparency of the IPSS?

To answer the research problem, the following research questions were formulated:

Q1: Is the adoption of an institutional website a common practice among the IPSS?

Q2: What is the quality level of IPSS websites?

Q3: What is the level of disclosure of financial, budgetary and performance information on the IPSS websites?

Q4: What is the level of maturity of online services available on IPSS websites?

Given the questions posed in this study, the methodology to be followed will be qualitative and quantitative (Augusto, 2014 [45]). The qualitative methodology will be used in the collection of data from the IPSS websites according to the EAGLE transparency index (This index aimed to enhance the frequent evaluation of the websites of public administrations in Portugal (Santos et al., 2018) [3], through the analysis of the following four dimensions: online presence, online quality, online accountability and online service, and it was adapted for the evaluation of the transparency of IPSS.) and the quantitative methodology involves the analysis and processing of the collected data. In particular, some measures of descriptive statistics were used. This index has the advantage of assessing the maturity of accountability of websites in a simple way of organisations or any kind of institution that works mainly with public or donated capital. So, we decided to use the 
EAGLE index, because it is a new index which can be adapted to the different kinds of public or private organisms in addition to being holistic (Santos et al., 2018) [3].

\subsection{Characterisation of the Sample}

To collect the sample, we used the lists made available by the social security on their website, (https: / / www.seg-social.pt/publicacoes?bundleId=16414310, accessed on 3 May 2021.) where the IPSS are divided into the following three lists: list of registered cooperatives, list of registered People's House and list of registered private social solidarity institutions. In this last list are included the IPSS with the following juridical nature: association, institute of religious organisation, parish social centre, mercy and foundation. On consulting these lists it was verified that in mainland Portugal there are 5342 entities with the IPSS status registered in social security. Using the criterion "belongs to the municipality of Porto", 190 institutions were collected, including 144 associations, 16 institutes of religious organisation, 17 parish social centres, 1 mercy, 6 foundations, 6 cooperatives and no People's House. The municipality of Porto was chosen as it corresponds to a geographical area in the north of Portugal with a high incidence of IPSS.

Data collection for assessing the transparency of IPSS through institutional websites was thus carried out based on the EAGLE index and occurred during the months of April and May 2021.

\subsection{Definition and Calculation of Variables}

The EAGLE index is the measure of the transparency of the IPSS and is divided into four dimensions, each with a specific weight (Table 1).

Table 1. Weight of EAGLE index dimensions.

\begin{tabular}{ccc}
\hline \multicolumn{2}{c}{ Dimensions } & Weight \\
\hline 1 & Online Presence & $10 \%$ \\
2 & Online Quality & $30 \%$ \\
3 & Online Accountability & $30 \%$ \\
4 & Online Service & $30 \%$ \\
\hline
\end{tabular}

Source: Prepared by the author.

Each dimension is divided into criteria and each of the criteria is subdivided into a set of indicators (most of which are scored between 0 -no-and $1-$ yes). Within each criterion, equal weight is attributed to each indicator, whereby the calculation of the weight of each indicator, for each criterion, is carried out using the following formula:

$$
\text { WeightIND } D_{j}=\frac{100}{T_{j}}
$$

WeightIND $D_{j}$ weight to be assigned to the indicators in criterion $j$;

$T_{j}$ : number of indicators in criterion $j$.

After calculating the weight of each indicator, its value is calculated using the following formula:

$$
\text { ValueIND } D_{j}=\text { WeightIND } D_{j} \times C A_{j}
$$

ValueIND $D_{j}$ : value assigned to the indicator for criterion $j$;

$C A_{j}$ : score given to each indicator in criterion $j$.

Therefore, the value attributed to each criterion corresponds to the sum of the values of all the indicators contained therein, calculated using the formula below:

$$
\text { ValueCRT }_{j}=\sum_{j=1}^{n} \text { ValueIND }_{j}
$$

ValueCRT $T_{j}$ : value assigned to criterion $j$; 
$n$ : number of indicators in criterion $j$.

The following formula is used to calculate the value assigned to each dimension of the EAGLE index:

$$
\text { ValueCRT }_{j}=\sum_{j=1}^{n} \text { ValueIND }_{j}
$$

ValueDIM $i$ : value assigned to dimension $i$;

$n$ : número de critérios na dimensão $i$.

Finally, the final score of the EAGLE index for the institutional website of each IPSS is calculated by adding the value of all dimensions:

$$
\text { EAGLEIndex }{ }_{k}=\sum_{i=1}^{n} \text { ValueDIM }_{i}
$$

EAGLEIndex $x_{k}$ level of transparency of the IPPS $k$.

$n$ : number of EAGLE index dimensions

In relation to the first dimension, Table 2, this is related to the online presence of the institution, that is to say, it is verified whether or not there is an institutional website.

Table 2. Online presence dimension indicators.

\begin{tabular}{cccccc}
\hline Dimension & Criterion & Weight & Indicators & $\begin{array}{c}\text { Measures } \\
\text { (Scale) }\end{array}$ & Weight \\
\hline \multirow{2}{*}{$\begin{array}{c}\text { Not } \\
\text { applicable }\end{array}$} & $100.00 \%$ & $\begin{array}{c}\text { The institution } \\
\text { doesn't have an } \\
\text { active website }\end{array}$ & 0 & $0.00 \%$ \\
\cline { 3 - 6 } & & $\begin{array}{c}\text { The institution has } \\
\text { an active website }\end{array}$ & 1 & $100.00 \%$ \\
\cline { 2 - 6 } & DIMpresence & $100.00 \%$ & & $100.00 \%$ \\
\hline
\end{tabular}

Source: EAGLE index.

In the second dimension, which concerns the quality of the website and the information it contains, the following criteria are used: functionality, reliability, usability, efficiency and security, detailed in Table 3.

In the first indicator of the functionality criterion, in order to assess the level of accessibility of the website for people with disabilities, the Accessmonitor tool is used, an automatic validator of web accessibility practices that uses in the evaluation a scale of 0 to 10. Regarding the date of the last update, the following scale measure was considered: 0 if the update occurred more than 61 days ago; 1 if the update occurred between (31-60 days); 2 if the update occurred between (16-30 days); 3 if the update occurred between (6-15 days) and 4 if the update occurred between ( $0-5$ days). The evaluation of the information on the services provided is based on the disclosure of the following data: the person in charge of the department, the opening hours of the service, the price charged and the capacity of users in the service. The measurement scale varies between 0 and 4 points, with 0 being evaluated if there is no information, 1 if at least one of the listed elements is present, 2 if at least two of the listed elements are present, 3 if at least three of the listed elements are present or 4 if all of the listed elements are present. As for the general appreciation of the website, this indicator is analysed with the help of the Website Grader tool, where performance, optimisation, security and compatibility for mobile devices are assessed. 
Table 3. Online quality dimension indicators.

\begin{tabular}{|c|c|c|c|c|c|}
\hline Dimension & Criterion & Weight & Indicators & $\begin{array}{l}\text { Measures } \\
\text { (Scale) }\end{array}$ & Weight \\
\hline \multirow{34}{*}{ 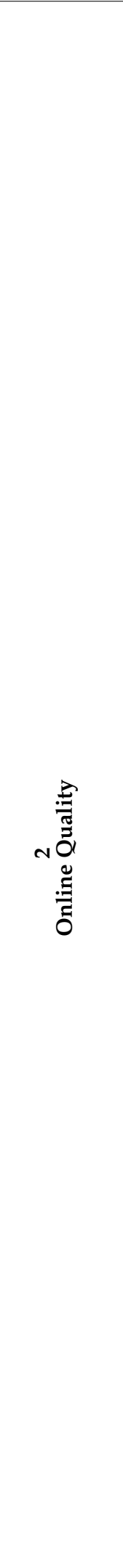 } & \multirow{11}{*}{ Funcionality } & \multirow{11}{*}{$20.00 \%$} & Conformity with "A", "AA" or "AAA" level & 1 a 10 & $10.00 \%$ \\
\hline & & & $\begin{array}{c}\text { The conformity symbol "A", "AA" or "AAA" is available on the } \\
\text { website homepage }\end{array}$ & $0 / 1$ & $10.00 \%$ \\
\hline & & & Date of last website update & {$[0,45]$} & $10.00 \%$ \\
\hline & & & $\begin{array}{c}\text { The entity responsible for website maintenance is } \\
\text { clearly identified }\end{array}$ & $0 / 1$ & $10.00 \%$ \\
\hline & & & $\begin{array}{c}\text { Information about services provided (responsible person, } \\
\text { schedule, price and capacity) }\end{array}$ & {$[0,45]$} & $10.00 \%$ \\
\hline & & & The entity responsible for the website is clearly identified & $0 / 1$ & $10.00 \%$ \\
\hline & & & Map with the location of the institution or GPS coordinates & $0 / 1$ & $10.00 \%$ \\
\hline & & & $\begin{array}{l}\text { The website can be accessed publically (free of taxes, register } \\
\text { or other) }\end{array}$ & $0 / 1$ & $10.00 \%$ \\
\hline & & & The website has an appropriate URL, easy to remember & $0 / 1$ & $10.00 \%$ \\
\hline & & & Overall assessment (Overview) & 0 a 100 & $10.00 \%$ \\
\hline & & & CRTf & - & $100.00 \%$ \\
\hline & \multirow{6}{*}{ Reliability } & \multirow{6}{*}{$20.00 \%$} & Pictures, graphs and tables used have clear captions & $0 / 1$ & $20.00 \%$ \\
\hline & & & $\begin{array}{l}\text { There is a search engine for internal search (search mechanism on } \\
\text { the website) }\end{array}$ & $0 / 1$ & $20.00 \%$ \\
\hline & & & $\begin{array}{c}\text { The author(s) of the information provided or the sources used are } \\
\text { clearly identified }\end{array}$ & $0 / 1$ & $20.00 \%$ \\
\hline & & & $\begin{array}{l}\text { The website provides information, content or the service } \\
\text { requested by the user }\end{array}$ & $0 / 1$ & $20.00 \%$ \\
\hline & & & Well-written and understandable text & $0 / 1$ & $20.00 \%$ \\
\hline & & & CRTr & - & $100.00 \%$ \\
\hline & \multirow{6}{*}{ Usability } & \multirow{6}{*}{$20.00 \%$} & There is information about services and content & $0 / 1$ & $20.00 \%$ \\
\hline & & & A map of the website is provided & $0 / 1$ & $20.00 \%$ \\
\hline & & & A help option is available (anywhere on the website) & $0 / 1$ & $20.00 \%$ \\
\hline & & & Different content is clearly identified & $0 / 1$ & $20.00 \%$ \\
\hline & & & There are navigation controls on every page & $0 / 0.5 / 1$ & $20.00 \%$ \\
\hline & & & CRTu & - & $100.00 \%$ \\
\hline & \multirow{6}{*}{ Efficiency } & \multirow{6}{*}{$20.00 \%$} & Invalid hyperlinks ( $1-\mathrm{No} ; 0$-Yes) & $0 / 1$ & $20.00 \%$ \\
\hline & & & Useful hyperlinks for the institution and users & $0 / 1$ & $20.00 \%$ \\
\hline & & & Possibility of selecting content in one or different languages & $0 / 1$ & $20.00 \%$ \\
\hline & & & $\begin{array}{l}\text { Multibrowser support (the website provides information on } \\
\text { compatible browsers) }\end{array}$ & $0 / 1$ & $20.00 \%$ \\
\hline & & & Load time & 0 a 100 & $20.00 \%$ \\
\hline & & & CRTe & - & $100.00 \%$ \\
\hline & \multirow{4}{*}{ Security } & \multirow{4}{*}{$20.00 \%$} & Communication with the website is encrypted (secure channel) & $0 / 1$ & $33.33 \%$ \\
\hline & & & Cookies warning & $0 / 1$ & $33.33 \%$ \\
\hline & & & The user is informed about data protection procedures & $0 / 1$ & $33.33 \%$ \\
\hline & & & CRTs & - & $100.00 \%$ \\
\hline & DIMquality & $100.00 \%$ & & - & $100.00 \%$ \\
\hline
\end{tabular}

Source: EAGLE index adapted. 
In the criterion regarding the usability of the website, in order to check if there is a map of the website, the Sitemap Test is used (https://seomator.com/free-tools/sitemap-test accessed date: 13 May 2021). As for the efficiency criterion, the Link Checker (https: / / validator.w3.org/checklink accessed date: 16 May 2021) was used to check for invalid links and, to assess loading time, Google's PageSpeed Insights (https:/ / developers.google. com/speed/pagespeed/insights / accessed date: 25 May 2021) tool is used under the "computer" tab.

Regarding the third dimension, online accountability, the level of disclosure of financial, budget and performance information is assessed, and, to this end, the following criteria were considered: accounting information, financial information characteristics, organisational performance and social performance. As for the indicators contained therein, they are presented in Table 4.

In this research, only the financial statements of 2019 were considered, since at the time of the study, the institutions were still in the process of closing accounts for 2020. We only assessed the characteristics of the financial information when all the mandatory financial statements are disclosed (balance sheet, income statement by nature, cash flow statement and annex). According to the conceptual framework, the main qualitative characteristics of financial information are the following: relevance; reliability; understandability; and comparability.

The financial information to be relevant must be timely, i.e., it must be timely provided to its users, otherwise it loses opportunity becoming only historical and devoid of other utility, (Antão et al., 2012 [8]). Therefore, in this indicator only the financial information for 2019 is considered relevant.

To possess the quality of reliability, the information must be free from material error and bias. The International Standards on Auditing 200 (ISA 200), in its paragraphs A28-A52, requires that the auditor obtains reasonable assurance about the financial statements as a whole, that is to say, that they are free from material misstatement, whether due to fraud or error. Therefore, in validating this indicator, the existence of a report by the statutory auditors or whether the financial statements are simultaneously signed by the certified accountant and by the management body can be verified.

Understandability determines that financial information should be easily understood by its users. Therefore, when analysing this indicator, attention should be paid to whether the notes to the financial statements contain explanatory text for the tables presented.

In addition, users must also be able to compare the financial statements of an entity over time and across different entities in order to assess its financial position, performance and changes in its financial position relatively. Therefore, in this indicator, the financial statements must present figures for the year of the financial year and the previous year, in accordance with the templates provided by the Accounting Standardisation System-NonProfit Sector Entities (SNC-ESNL) and be published for the years 2020 and 2021.

Regarding the fourth and last dimension, maturity of online services, the entities will be analysed according to the following criteria: participation, transaction and customisation, as per Table 5 .

The criterion "Mobile performance of the site" was evaluated with the help of Google's PageSpeed Insights (https:/ / developers.google.com/speed/pagespeed/insights/) accessed on tool in the "mobile phones" tab (14 December 2021). 
Table 4. Online accountability dimension indicators.

\begin{tabular}{|c|c|c|c|c|c|}
\hline Dimension & Criterion & Weight & Indicators & $\begin{array}{l}\text { Measures } \\
\text { (Scale) }\end{array}$ & Weight \\
\hline \multirow{36}{*}{ 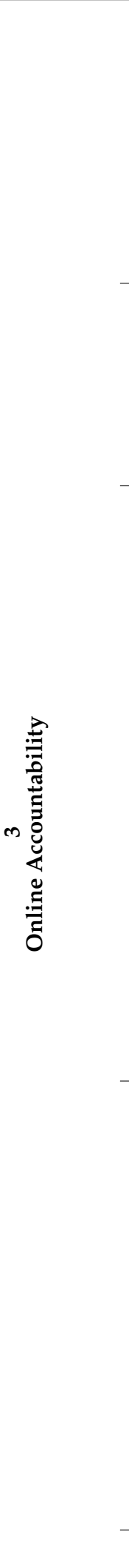 } & \multirow{7}{*}{ Accounting information } & \multirow{7}{*}{$25.00 \%$} & Balance sheet & $0 / 1$ & $16.67 \%$ \\
\hline & & & Income statements by nature & $0 / 1$ & $16.67 \%$ \\
\hline & & & Income Statement by Functions & $0 / 1$ & $16.67 \%$ \\
\hline & & & Statement of changes in equity & $0 / 1$ & $16.67 \%$ \\
\hline & & & Cash flow statement & $0 / 1$ & $16.67 \%$ \\
\hline & & & Annex to the financial statements & $0 / 1$ & $16.67 \%$ \\
\hline & & & CRTai & & $100.00 \%$ \\
\hline & \multirow{5}{*}{$\begin{array}{l}\text { Characteristics of } \\
\text { financial information }\end{array}$} & \multirow{5}{*}{$25.00 \%$} & Relevance & $0 / 1$ & $25.00 \%$ \\
\hline & & & Reliability & $0 / 1$ & $25.00 \%$ \\
\hline & & & Comprehensibility or clarity & $0 / 1$ & $25.00 \%$ \\
\hline & & & Comparability & $0 / 1$ & $25.00 \%$ \\
\hline & & & CRTifc & - & $100.00 \%$ \\
\hline & \multirow{14}{*}{$\begin{array}{l}\text { Organisational } \\
\text { Performance }\end{array}$} & \multirow{14}{*}{$25.00 \%$} & Statistics, publications and studies & $0 / 1$ & $7.69 \%$ \\
\hline & & & Organisational structure (organogram) & $0 / 1$ & $7.69 \%$ \\
\hline & & & Programmed or ongoing events & $0 / 1$ & $7.69 \%$ \\
\hline & & & Key performance indicators & $0 / 1$ & $7.69 \%$ \\
\hline & & & Institutional information (vision, mission, objectives) & $0 / 0,5 / 1$ & $7.69 \%$ \\
\hline & & & Information on organisational culture & $0 / 1$ & $7.69 \%$ \\
\hline & & & Information on the history of the organisation & $0 / 1$ & $7.69 \%$ \\
\hline & & & Human Resources organisation & $0 / 1$ & $7.69 \%$ \\
\hline & & & Approved budget for the current year & $0 / 1$ & $7.69 \%$ \\
\hline & & & Budget execution & $0 / 1$ & $7.69 \%$ \\
\hline & & & $\begin{array}{c}\text { Plan of activities (Action program for the } \\
\text { current year) }\end{array}$ & $0 / 1$ & $7.69 \%$ \\
\hline & & & Strategic plan & $0 / 1$ & $7.69 \%$ \\
\hline & & & Cooperation agreements and protocols & $0 / 1$ & $7.69 \%$ \\
\hline & & & CRTop & - & $100.00 \%$ \\
\hline & \multirow{9}{*}{ Social Performance } & \multirow{9}{*}{$25.00 \%$} & Document archives are available & $0 / 1$ & $12.50 \%$ \\
\hline & & & Minutes of government bodies are available & $0 / 1$ & $12.50 \%$ \\
\hline & & & Contacts (email, phone, fax, etc.) & $0 / 1$ & $12.50 \%$ \\
\hline & & & Relevant legislation for users & $0 / 1$ & $12.50 \%$ \\
\hline & & & Remuneration of management bodies & $0 / 1$ & $12.50 \%$ \\
\hline & & & Composition of corporate bodies (identification) & $0 / 1$ & $12.50 \%$ \\
\hline & & & $\begin{array}{l}\text { Biographical note of the members of the } \\
\text { management bodies }\end{array}$ & $0 / 1$ & $12.50 \%$ \\
\hline & & & $\begin{array}{l}\text { Disclosure of social responsibility policies (describe } \\
\text { what we want to measure: local suppliers; social } \\
\text { stores; inclusive policies; energy efficiency) }\end{array}$ & {$[0,9]$} & $12.50 \%$ \\
\hline & & & CRTsp & - & $100.00 \%$ \\
\hline & DIMaccountability & $100.00 \%$ & & - & $100.00 \%$ \\
\hline
\end{tabular}


Table 5. Online services dimension indicators.

\begin{tabular}{|c|c|c|c|c|c|}
\hline \multirow{16}{*}{ 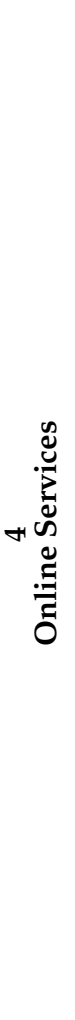 } & \multirow{6}{*}{ Participation } & \multirow{6}{*}{$20.00 \%$} & Forms for services provided are available for download & $0 / 1$ & $20.00 \%$ \\
\hline & & & There is room for questions & $0 / 1$ & $20.00 \%$ \\
\hline & & & $\begin{array}{c}\text { There is a debate forum (complaints, improvement } \\
\text { suggestions, etc.) }\end{array}$ & $0 / 1$ & $20.00 \%$ \\
\hline & & & Possibility of subscribing a newsletter & $0 / 1$ & $20.00 \%$ \\
\hline & & & Presence in social networks & $0 / 1$ & $20.00 \%$ \\
\hline & & & CRTpt & - & $100.00 \%$ \\
\hline & & & $\begin{array}{l}\text { Possibility of checking online the status of any } \\
\text { procedure free of legal restrictions }\end{array}$ & $0 / 1$ & $25.00 \%$ \\
\hline & & & Possibility of uploading multimedia content & $0 / 1$ & $25.00 \%$ \\
\hline & Transaction & $40.00 \%$ & Possibility of making payments online & $0 / 1$ & $25.00 \%$ \\
\hline & & & Online payment options & $0 / 1$ & $25.00 \%$ \\
\hline & & & CRTtr & - & $100.00 \%$ \\
\hline & & & $\begin{array}{l}\text { Possibility of follow up for services provided, ensuring } \\
\text { data protection compliance }\end{array}$ & $0 / 1$ & $33.33 \%$ \\
\hline & Customisation & $40.00 \%$ & $\begin{array}{l}\text { Possibility of real-time interaction for further } \\
\text { information, ensuring data protection compliance }\end{array}$ & $0 / 1$ & $33.33 \%$ \\
\hline & & & Mobile site performance & 0 a 100 & $33.33 \%$ \\
\hline & & & CRTps & - & $100.00 \%$ \\
\hline & DIMonlineserv & $100.00 \%$ & & & \\
\hline EA & Index & $100.00 \%$ & & & $100.00 \%$ \\
\hline
\end{tabular}

\section{Analysis and Discussion of Results}

This section analyses and discusses the results and answers the research questions posed. Q1 Is it common practice for IPSS to adopt an institutional website?

Thus, to answer Q1 we began by analysing the first dimension of the index, online presence, which enabled the identification that, of the 190 IPSS in the municipality of Porto, 56 had no website, corresponding to $29.47 \%$ of the IPSS in the sample (Table 6). Seven years after the implementation of the obligation set out in Decree-Law No. 172-A/2014 [39], only $70.53 \%$ of the IPSS are able to comply with it. Considering the legal nature of the IPSS with a site, most of the institutions are associations, around $70 \%$, followed by parish social centres, $11 \%$, and institutes of religious organisation, $9 \%$.

For a more detailed analysis, Table 6 shows that all the foundations, cooperatives and misericórdia in the municipality have a website, i.e., they are able to comply with the obligation to publish their accounts on the institutional website. On the other hand, $34.72 \%$ of the associations, $25 \%$ of the institutes of religious organisation and $11.76 \%$ of the parish social centres do not have an institutional website.

The results presented allow answering the research question Q1, showing that $70.53 \%$ of the IPSS have an institutional website, a result very close to the 71\% that Bandeira et al. (2020) [2], demonstrated in the study carried out based on the institutions of the autonomous region of Madeira. In relation to the study of Ferreira et al. (2016) [1], there was a significant improvement in relation to the $37.62 \%$ determined by these authors, as well as the study that the same authors conducted later, Ferreira et al. (2019) [40], in which they determined some improvements in relation to the previous one (about 37.86\%). Pardal et al. (2019) [41] demonstrated that only $47 \%$ of the IPSS in the municipality of Setúbal had an institutional website. 
Table 6. Online presence of the IPSS of Porto City Council.

\begin{tabular}{cccccc}
\hline \multirow{2}{*}{ Legal Nature } & $\begin{array}{c}\text { Nr. of IPSS Porto } \\
\text { City Council }\end{array}$ & \multicolumn{2}{c}{$\begin{array}{c}\text { IPSS with } \\
\text { Institutional Site }\end{array}$} & \multicolumn{2}{c}{$\begin{array}{c}\text { IPSS without } \\
\text { Institutional Site }\end{array}$} \\
\cline { 2 - 6 } & 144 & $\mathbf{N r}$ & $\%$ & $\mathbf{N r}$ & $\%$ \\
\hline Association & 16 & 94 & $65.28 \%$ & 50 & $34.72 \%$ \\
\hline $\begin{array}{c}\text { Institute for } \\
\text { Religious } \\
\text { Organisation }\end{array}$ & 17 & 12 & $75.00 \%$ & 4 & $25.00 \%$ \\
\hline Parish Social Centre & 1 & 15 & $88.24 \%$ & 2 & $11.76 \%$ \\
\hline Misericórdia & 6 & 1 & $100 \%$ & 0 & $0 \%$ \\
\hline Foundation & 6 & 6 & $100 \%$ & 0 & $0 \%$ \\
\hline Cooperative & 190 & 6 & $100 \%$ & 0 & $0 \%$ \\
\hline Total & 134 & $70.53 \%$ & 56 & $29.47 \%$ \\
\hline Source: Prepared by the author. & & & & &
\end{tabular}

Source: Prepared by the author.

Q2: What is the quality level of the IPSS institutional websites?

As referred beforehand, the second dimension of the EAGLE index is related to the quality of the institutional website and the information it contains. Table 7 shows the dimension subdivided into the five criteria and the average score of the IPSS, by legal nature, per each criterion.

Table 7. Average score of the IPSS, by legal nature, in the online quality criteria.

\begin{tabular}{|c|c|c|c|c|c|c|c|}
\hline \multirow{2}{*}{ Legal Nature } & \multicolumn{7}{|c|}{ Criteria } \\
\hline & Functionality & Reliability & & ility & Effi & ency & Security \\
\hline Association & 3.22 & 4.31 & & & & & 3.15 \\
\hline Institute for Religious Organisation & 3.32 & 3.70 & & & & & 3.67 \\
\hline Parish Social Centre & 3.43 & 3.76 & & & & & 2.13 \\
\hline Misericórdia & 3.91 & 3.60 & & & & & 6.00 \\
\hline Foundation & 3.06 & 4.40 & & & & & 2.67 \\
\hline Cooperative & 3.38 & 3.80 & & & & & 1.33 \\
\hline Average & $54.33 \%$ & $69.50 \%$ & 4.40 & $73.33 \%$ & 2.48 & $41.33 \%$ & $3.00 \quad 50.00 \%$ \\
\hline Scale & 0 a 6 & 0 a 6 & & & & & 0 a 6 \\
\hline
\end{tabular}

Source: Prepared by the author.

Of all the criteria in this dimension, efficiency is the one that presents the lowest average, being around $41.33 \%$ of the maximum possible score. Both functionality and security present an average around $50 \%$, and the reliability and usability criteria are the ones which present the highest average, around $70 \%$. Furthermore, in the same table, we can verify that, considering the legal nature, the values in each criterion do not vary much among themselves, except in the security criterion, where misericórdia shows the maximum score and the cooperatives an average of 1.33 points out of 6 . In this criterion, communication with the website is evaluated, i.e., if it is conducted securely, if the user is informed about the use of cookies and about the procedures regarding data protection. It was found that only 35 institutions respected these three indicators, 67 between one and two indicators and 32 did not respect any of the indicators.

Regarding the functionality criterion, this refers to the website functionalities and is composed of indicators that help validate the relevance of the information provided from the user's perspective, by assessing the accuracy of the information, ease of access and navigability. With regard to information on the services provided and taking into account the four parameters referred to above for the analysis of this indicator, around $36 \%$ of the 
IPSS did not comply with any of them, 31\% complied with only one and $2 \%$ (3 institutions) complied with all four parameters. This means that the accuracy of the information is not at the desired quality level given that the parameters selected are considered as the basic information for the service provided by the institution. On the other hand, accessibility is a set of features associated with a website that facilitate the use to all users, whether they are disabled or not (Santos et al., 2018) [3]. On average, the level of accessibility of websites for people with disabilities, is at $47 \%$. Considering that the guiding principles of the social economy include respect for the values of equality and non-discrimination, the accessibility level of $47 \%$ is unsatisfactory, thus demonstrating that institutions need to adapt their websites to all types of users. Finally, using the Website Grader tool, it was found that the level of navigability of the sites is $65 \%$, which is considered a reasonable value.

In turn, the reliability criterion is related to the website features that ensure that the information provided is properly identified and meets users' needs. From the analysis carried out, it was found that only $23 \%$ of the IPSS have an internal search engine on the website and $92 \%$ provide the information, content or service requested by the user.

The usability criterion evaluates the mechanisms of the site to ensure efficient use, whether it fulfils the intended function and whether it provides mechanisms to minimise user's errors, among other aspects. It was found that about $83 \%$ of the institutions have any information regarding their services and contents and that $60 \%$ of the websites have a help option available.

Finally, the efficiency criterion is related to the website response time and to the user's needs. According to the scale provided by Google's PageSpeed Insights tool, 31\% of the institutions are at the "poor" level, between 0 and 49, on the website loading time scale, $39 \%$ at the "needs improvement" level and 30\% at the "good" level. Furthermore, still on this criterion, it can be verified that only seven institutions (5\%), mainly associations, make available the option to select content in another language or in several languages, thus respecting the values of social economy entities.

Thus, in response to Q2, the level of quality of the websites is still below ideal, as the online quality dimension, despite presenting the highest average among the others, demonstrates that the institutions do not disclose relevant information on the services provided on their respective websites. Furthermore, there needs to be a review of access to other languages, as well as access for users with disabilities, so as to respect the guiding principles of social economy entities. These results are in line with the results obtained by Ferreira et al. (2016), in which they refer that the content provided on the IPSS websites did not meet the minimum indicators selected in the index used.

Q3 What is the level of disclosure of financial, budgetary and performance information on the IPSS websites?

To answer Q3 we investigated the third dimension of the EAGLE index, online accountability, where the financial, budgetary and performance information made available on the institution's website was analysed. To this end, the dimension was divided into four criteria, whose results we can analyse from Table 8.

An analysis of Table 8 shows that not even half of the maximum score was achieved in the four criteria, with social performance achieving the lowest average score at $30.80 \%$ of the scale. Since the criterion related to the analysis of the characteristics of the financial information depends on the accounting information made available, both should have an identical average score. This is not verified (12.26\% difference between the two criteria), thus presuming that the entities do not disclose all the mandatory financial statements. Considering the legal nature, parish social centres and misericórdia are those that present the highest values in the first two criteria and foundations in the remaining criteria. 
Table 8. Average score of the IPSS, by legal nature, in the online accountability criteria.

\begin{tabular}{|c|c|c|c|c|}
\hline \multirow[b]{2}{*}{ Legal Nature } & \multicolumn{4}{|c|}{ Criteria } \\
\hline & $\begin{array}{l}\text { Accounting } \\
\text { Information }\end{array}$ & $\begin{array}{l}\text { Characteristics of } \\
\text { Financial Information }\end{array}$ & $\begin{array}{l}\text { Organisational } \\
\text { Performance }\end{array}$ & $\begin{array}{c}\text { Social } \\
\text { Performance }\end{array}$ \\
\hline Association & 3.23 & 2.12 & 2.40 & 2.37 \\
\hline Institute for Religious Organisation & 3.44 & 3.13 & 2.44 & 1.85 \\
\hline Parish Social Centre & 4.58 & 4.38 & 2.59 & 2.27 \\
\hline Misericórdia & 6.25 & 5.63 & 0.00 & 2.77 \\
\hline Foundation & 3.33 & 3.13 & 2.91 & 2.73 \\
\hline Cooperative & 2.71 & 0.94 & 1.80 & 1.84 \\
\hline Average & $45.33 \%$ & $33.07 \%$ & $32.13 \%$ & $30.80 \%$ \\
\hline Scale & 0 a 7.5 & 0 a 7.5 & 0 a 7.5 & 0 a 7.5 \\
\hline
\end{tabular}

Source: Prepared by the author.

In the accounting information criterion, it is analysed whether the entity complies with the publication of the 2019 financial statements. It was possible to verify that only $38.81 \%$ of the IPSS published all the mandatory financial statements and $27.61 \%$ did not publish any of the financial statements. Thus, we can state that $61.19 \%$ of the entities analysed are in breach of the obligation to publish accounts on the institutional website (Decree-Law No. 172-A/14) [39], as they do not publish all mandatory financial statements. Despite this, the balance sheet and income statement by Nature are the ones with the highest percentage of publication $(71.64 \%)$, followed by the annex $(52.99 \%)$ and the cash flow statement $(44.03 \%)$. The remaining financial statements show a lower percentage of publication, as they are not of compulsory publication, being $18.66 \%$ for the income statement by functions and $13.43 \%$ for the statement of changes in patrimonial funds.

The second criterion corresponds to the analysis of the characteristics of financial information and it can only be carried out when all the mandatory financial statements are published on the institutional website. Of the entities that respected this condition, $52(38.81 \%)$, only $20(38.46 \%)$ presented financial information that was relevant, reliable, understandable and comparable with previous years. All of them had relevant information, however, 14 entities did not publish the information duly signed, simultaneously, by the certified accountant and the management body or the absence of the statutory auditors report was verified, 12 entities did not present explanatory text regarding the tables, thus risking the characteristic of understandability and, finally, in 11 entities it was not possible to verify the comparability of the information, as they did not publish the accounts for the financial years 2017 and 2018.

In as much as organisational performance is concerned, this criterion is associated with the evaluation of non-financial organisational performance whereby the presentation of the institution is verified, i.e., if the same publishes its vision, mission and objectives on the website. It was verified that $24.63 \%$ of the institutions do not publish any of these elements, $19.40 \%$ publish only some of them and the remaining IPSS (55.97\%) present all three elements. As regards the disclosure of cooperation agreements and protocols, around $58.21 \%$ of the entities analysed disclosed this information. Furthermore, it was also possible to verify that only $20.90 \%$ of the institutions published the 2021 activities plan and the same percentage published the 2021 Budget.

Finally, the social performance criterion is related to the evaluation of organisational participation in civil society. One of the indicators of this criterion consists of verifying if the institution's contacts are made available on the website, such as the address, telephone, social networks or Internet messaging, and it was found that $19.40 \%$ of the IPSS provided up to two of these components and only $38.81 \%$ presented all contacts. Additionally, in this criterion, it is possible to verify that $66.42 \%$ of the institutions disclosed the composi- 
tion of the governing bodies and that only $5.22 \%$ published minutes of the institution's governing bodies.

Thus, the answer to Q3, more specifically as regards the results of the online accountability dimension, shows that seven years after the entry into force of Decree-Law No. $172-A / 14$ [39], $61.19 \%$ of the IPSS analysed do not comply with the duty to publish accounts for the financial year on the institution's website by 31 May of the following year to which they relate, being a strong indicator of lack of financial transparency, in line with the results obtained by Tomé et al. (2016) [46], Bandeira et al. (2020) [2] and Pardal et al. (2019) [41]. Furthermore, it was found that more than half of the institutions that published accounting information did not meet the main qualitative characteristics, according to the conceptual framework, of this information. Even so, resistance was noted in relation to the disclosure of the institutions' performance, i.e., the absence of management reports, budgets, activity plans and other performance indicators. In order to achieve a reasonable level of financial transparency, institutions should not only comply with the aforementioned obligation but also take the initiative to publish performance indicators and respect the main qualitative characteristics of financial information.

Q4: What is the level of maturity of the online services available on the IPSS websites?

Finally, the last dimension of the EAGLE index, online services, is based on an assessment of the availability and quality of online services (Table 9).

Table 9. Average score of the IPSS, by legal nature, in the online services criteria.

\begin{tabular}{|c|c|c|c|}
\hline \multirow{2}{*}{ Legal Nature } & \multicolumn{3}{|c|}{ Criteria } \\
\hline & Participation & Transaction & Personalisation \\
\hline Association & 3.19 & 0.11 & 1.63 \\
\hline Institute for Religious Organisation & 3.17 & 0.21 & 1.06 \\
\hline Parish Social Centre & 2.67 & 0.00 & 1.49 \\
\hline Misericórdia & 4.00 & 0.00 & 2.00 \\
\hline Foundation & 3.67 & 0.83 & 1.16 \\
\hline Cooperative & 2.00 & 0.00 & 1.91 \\
\hline Average & $31.20 \%$ & $1.30 \%$ & $15.50 \%$ \\
\hline Scale & 0 a 10 & 0 a 10 & 0 a 10 \\
\hline
\end{tabular}

By analysing Table 9, it is possible to verify that the three criteria present a very low score. The criterion with the highest average is participation, covering only $31.20 \%$ of its scale, followed by personalisation with $15.50 \%$ and, lastly, transaction with approximately $1.30 \%$. In terms of legal nature, misericórdia is the one that presents the highest average in participation and in personalisation but, together with the parish social centres and the cooperatives, in transaction it displays zero score.

The participation criterion assesses the possibility of stakeholder participation in initiatives promoted by the institution. It was verified that $11.19 \%$ of the IPSS provided application forms for their services, $61.19 \%$ had a specific place to ask questions to the institution and $61.94 \%$ contained information on the social networks used by the institution.

In the transaction criterion, it is analysed the possibility of stakeholders to follow the procedures for payment of services provided by the institution. It was found that only two institutions granted the possibility to make the payment online.

Finally, the personalisation criterion verifies whether users can personalise some of the service parameters and, in only two IPSS, it is possible to enter and change data associated with the service provided. Again, using Google's PageSpeed Insights tool, but using the mobile tab, $58.21 \%$ of the institutions are at the "poor" level on the website loading time scale, $35.07 \%$ at the "needs improvement" level and $6.72 \%$ at the "good" level. 
In response to $Q 4$, with regard to online quality, it was possible to verify that institutions still do not have the possibility of the user being able to consult and monitor the service provided online, thus demonstrating the non-monitoring of technological evolution in service provision, thus confirming the studies conducted by Ferreira et al. (2016) [1], Ferreira et al. (2019) [40] and by Pardal et al. (2019) [41]. In sum, the maturity level of the IPSS' online services is very low and needs reinforced attention, which explains the average score of 4.78 out of 30 on this dimension.

To answer the investigation problem in Table 9, we may observe the number of IPSS, in the municipality of Porto, which have websites, distributed by legal nature in each scale interval of the EAGLE index. The index in question is scored from 0 to 100 and, for the purposes of assessing transparency, was divided into five levels (Table 10) as follows: between 10 and 19 points, no transparency level; between 20 and 39 points, little transparency level; between 40 and 59 points, intermediate transparency level; between 60 and 79 points, good transparency level and, between 80 and 100 points, excellent transparency level.

Table 10. Number of IPSS, by legal nature, in each interval of the EAGLE index scale.

\begin{tabular}{|c|c|c|c|c|c|c|c|c|c|c|c|c|c|c|}
\hline \multirow{2}{*}{$\begin{array}{c}\text { EAGLE } \\
\text { Index Scale } \\
{[10 ; 20]}\end{array}$} & \multicolumn{2}{|c|}{ Association } & \multicolumn{2}{|c|}{$\begin{array}{l}\text { Institute for } \\
\text { Religious } \\
\text { Organisation }\end{array}$} & \multicolumn{2}{|c|}{$\begin{array}{c}\text { Parish } \\
\text { Social Centre }\end{array}$} & \multicolumn{2}{|c|}{ Misericórdia } & \multicolumn{2}{|c|}{ Foundation } & \multicolumn{2}{|c|}{ Cooperative } & \multicolumn{2}{|c|}{ Total } \\
\hline & 5 & $5.32 \%$ & 1 & $8.33 \%$ & - & - & - & - & - & - & - & - & 6 & $4.48 \%$ \\
\hline$[20 ; 40]$ & 65 & $69.15 \%$ & 5 & $41.67 \%$ & 10 & $66.67 \%$ & - & - & 4 & $66.67 \%$ & 5 & $83.33 \%$ & 89 & $66.42 \%$ \\
\hline$[40 ; 60]$ & 23 & $24.47 \%$ & 6 & $50.00 \%$ & 5 & $33.33 \%$ & 1 & $100 \%$ & 2 & $33.33 \%$ & 1 & $16.67 \%$ & 38 & $28.36 \%$ \\
\hline$[60 ; 80]$ & 1 & $1.06 \%$ & - & - & - & - & - & - & - & - & - & - & 1 & $0.74 \%$ \\
\hline$[80 ; 100]$ & - & - & - & - & - & - & - & - & - & - & - & - & - & - \\
\hline Total & 94 & $100 \%$ & 12 & $100 \%$ & 15 & $100 \%$ & 1 & $100 \%$ & 6 & $100 \%$ & 6 & $100 \%$ & 134 & $100 \%$ \\
\hline Average & \multicolumn{2}{|c|}{34} & \multicolumn{2}{|c|}{35} & \multicolumn{2}{|c|}{35} & \multicolumn{2}{|c|}{49} & \multicolumn{2}{|c|}{36} & \multicolumn{2}{|c|}{29} & \multicolumn{2}{|c|}{34} \\
\hline
\end{tabular}

Source: Prepared by the author.

On analysing Table 9, we may observe that, on average, the IPSS in the municipality of Porto have an overall transparency level of 34\% (34 out of 100 points in the EAGLE index), i.e., they have a low level of transparency. We also verify that the averages for associations, institutes of religious organisation, parish social centres and foundations are around the global average, in contrast to the cooperatives, which present an average that is 5 points lower.

According to the legal nature, around $69 \%$ of the Associations are situated on the second scale of the Index, thus presenting low transparency in their institutional websites, and $24.47 \%$ are at an intermediate level of transparency. With regard to the institutes of religious organisation, these are equally distributed between the second and third scale. Parish social centres and foundations present an equal distribution, i.e., approximately $67 \%$ of the entities show limited transparency and the remaining entities have an intermediate level of transparency. As for the cooperatives, the majority of these entities show low levels of transparency since they are located on the second scale of the index. Finally, the misericórdia of Oporto shows an intermediate level of transparency, standing at 49 points.

Looking in detail at the average score of the IPSS in each dimension of the EAGLE index (Table 11), we see that online quality has the highest average score, 17.30 out of 30 points, followed by online accountability with 10.62 points out of 30 and, finally, online services with an average of only 4.78 points out of 30 . 
Table 11. Average score of the IPSS, by legal nature, in each dimension of the EAGLE index.

\begin{tabular}{|c|c|c|c|}
\hline \multirow{2}{*}{ Legal Nature } & \multicolumn{3}{|c|}{ Dimension } \\
\hline & Online Quality & Online Accountability & Online Services \\
\hline Association & 17.62 & 10.34 & 4.74 \\
\hline $\begin{array}{l}\text { Institute for Religious } \\
\text { Organisation }\end{array}$ & 16.67 & 10.42 & 5.50 \\
\hline Parish Social Centre & 16.27 & 12.80 & 4.20 \\
\hline Misericórdia & 21.00 & 19.00 & 6.00 \\
\hline Foundation & 17.17 & 11.67 & 5.50 \\
\hline Cooperative & 15.67 & 7.50 & 4.50 \\
\hline Average & $57.67 \%$ & $35.40 \%$ & $15.93 \%$ \\
\hline Scale & 0 a 30 & 0 a 30 & 0 a 30 \\
\hline
\end{tabular}

Source: Prepared by the author.

In the second dimension, online quality, misericórdia has the highest average score (21 points), followed by the associations with approximately 18 points. In the third dimension, online accountability, misericórdia, with 19 points, and parish social centres, with approximately 13 points, are the ones with the highest average score. In turn, in the fourth dimension, online services, the highest average score belongs to misericórdia with 6 points, institutes of religious organisation and foundations with 5.50 points.

\section{Final Considerations}

From the various possible ways of analysing the level of transparency of the IPSS, this study opted to assess transparency from the institutional websites of the IPSSs of the municipality of Porto, using the EAGLE transparency index.

This study allows us to conclude that there are still IPSS that do not have a website (approximately 30\%). It also allows us to conclude that the average transparency index of the IPSS, although it has been improving, still presents very low values with the dimension of online services being the one with the worst results.

Based on the combined analysis of the results of the four dimensions of the EAGLE index, it was possible to answer the research problem. It is concluded that the average level of transparency of the IPSS of the municipality of Porto is around 34\%, which determines low transparency. Therefore, the expected results were not achieved, i.e., not only did the institutions not follow technological evolution but they also did not take advantage of the opportunity that the current pandemic situation provided them for the technological transition of their services.

This research highlights the importance of the TFA project, as institutions can use the project to improve their level of transparency, since it provides several tools for disclosing economic-financial, social and political information.

The results may be due to several factors. We believe that the lack of financial resources and the lack of professionalization of managers can help explain the fact that some of the IPSS still do not have a website and the low level of transparency (from these entities the vast majority of managers of these entities are volunteers and have a low level of education).

This study contributes to the literature on the transparency of entities. On the one hand, because it allowed us to test the EAGLE index and show that it is an adequate index for this purpose, thus providing a basis for evaluating other entities with a similar profile. On the other hand, because it contributes to the knowledge of the level of transparency of the IPSS.

From a practical point of view, the study can help IPSS realize that they can improve their performance and contribution to society if they increase the level of transparency. Through increased transparency, they can even increase the trust of different stakeholders and that fear, increase donations from patrons and donors. This is an important objective 
insofar as increasing funding in this way can increase its sustainability. The present study ends with the following recommendations for future research: apply the EAGLE index to other municipalities so that a comparative analysis can be made; study the reasons that lead institutions not to disclose the information or whether this disclosure depends on whether they are financed by Social Security and evaluate the level of transparency of the institutions through other criteria, such as, analysis of public tenders.

This study does not investigate the quality of the information provided, but only the presence of information on the websites. In this sense, future work could focus on the quality of the information disseminated.

On the other hand, our study analysed the websites of a sample of entities from the municipality of Porto, so the analysis was limited to a specific territory. It can, however, be considered that the municipality of Porto is representative of the population. Otherwise, it cannot be generalized to the whole territory and the reader should be aware of this fact, so a future development of this work should be to apply the EAGLE index to a representative sample and analyse comparatively the results with the present study, trying to identify if the behaviour of the entities in the municipality of Porto is identical to the population. The present study also does not analyse the factors that influence the level of transparency of the entities. Knowledge of these factors could lead to the establishment of policies and/or assistance to encourage entities to create the conditions to increase their level of transparency, particularly with regard to the size of online services.

Another limitation of this study is related to the subjectivity that underlies the analysis of the qualitative characteristics of financial information in the online reporting dimension. This limitation opens the door to the future development of metrics that allow for the reduction in this subjectivity.

Author Contributions: Conceptualization, all authors; Methodology, A.F., A.M.B., C.S. and I.F.; Formal analysis, A.F., A.M.B., C.S. and B.T.; investigation, all authors; writing-original draft preparation I.F., A.M.B., A.F. and B.T.; writing - review and editing A.F., A.M.B. and C.S.; supervision, A.F. and A.M.B.; project administration A.F. and A.M.B. All authors have read and agreed to the published version of the manuscript.

Funding: The European Regional Development Fund (FEDER), through Operational Competitiveness and Internationalisation Program (COMPETE 2020-POCI), and the Foundation for Science and Technology (FCT) financed this research, with reference number POCI-01-0145-FEDER-030074.

Institutional Review Board Statement: Not applicable.

Informed Consent Statement: Not applicable.

Data Availability Statement: Not applicable.

Conflicts of Interest: The authors declare no conflict of interest.

\section{References}

1. Ferreira, A.; Marques, R.P.; Santos, C.; Azevedo, G.; Mendes, H. Avaliação da presença na Internet das instituições particulares de solidariedade social portuguesas. Estud. ISCA 2016, 14, 1-16. [CrossRef]

2. Bandeira, A.; Ornelas, T.; Meira, D.; Azevedo, G. Transparência das Instituições Particulares de Solidariedade Social na Região Autónoma da Madeira: Estudo Empírico. Revista E3-Revista de Economia, Empresas e Empreendedores na CPLP. Indexed by Scientific Indexing Services, Indexcopernicus, Latindex, Open Academic Journals Index. 2020. Available online: https: // revistas.ponteditora.org/index.php/e3/indexacoes (accessed on 15 May 2021).

3. Santos, C.; Ferreira, A.D.C.S.; Marques, R.P.F.; Carmo Azevedo, G.M. EAGLE_Index: Enhancement of an accountability guide for learning E-Government. In Handbook of Research on Modernization and Accountability in Public Sector Management; IGI Global: Lisboa, Portugal, 2018; pp. 103-129. [CrossRef]

4. Barros, R.M.S. A Contabilidade no Âmbito da Economia Social. Ph.D. Thesis, Instituto Politécnico do Porto, Porto, Portugal, 2015.

5. Franco, R.C.; Sokolowski, S.W.; Hairel, E.M.; Salamon, L.M. O Sector Não Lucrativo Português Numa Perspectiva Comparada. Uniarte Gráfica. 2005. Available online: https://www.akdn.org/akdn/sites/akdn/files/Publications/2008_portugal_ nonprofitsector.pdf (accessed on 19 July 2021).

6. Basic Law of the Social Economy (LBES), Law No. 30/2013 of 8 May. Available online: https://www.casadaimprensa.pt/GetFile. ashx?FileID=26 (accessed on 15 December 2021). 
7. Meira, D.A. A Lei de Bases da Economia social Portuguesa. Breve Apresentação. Coop. Econ. Soc. 2013, 35. Available online: https:/ / www.cases.pt/wp-content/uploads/Cooperativismo_35.pdf (accessed on 14 November 2021).

8. Antão, A.A.; Tavares, A.; Marques, J.P.; Alves, S. Novo Regime da Normalização Contabilística para as Entidades do Setor Não Lucrativo; Áreas Editora: Lisboa, Portugal, 2012; ISBN 9789898058737.

9. Bandeira, A. O Regime de Normalização Contabilística Português para as Empresas do Setor Não Lucrativo-SNC-ESN-E as suas Especificidades Relativamente ao Relato Financeiro. Coop. Econ. Soc. 2013, 35, 223-230. Available online: https: // cases.pt/wp-content/uploads/Cooperativismo_35.pdf (accessed on 23 May 2021).

10. Bandeira, A.M. Enquadramento Contabilístico das Cooperativas em Portugal: Ponto de Situação Face às Recentes Alterações ao Normativo Contabilístico. Coop. Econ. Soc. 2016, 38, 357-366.

11. Vieira, T. Os Papéis da Organizações do Terceiro Setor na Resposta aos Problemas Sociais. Ph.D. Thesis, Faculdade de Economia da Universidade de Coimbra, Coimbra, Portugal, 2015. Available online: http://hdl.handle.net/10316/29684 (accessed on 11 November 2021).

12. Vieira, N.D.S.; Parente, C.; Barbosa, A.C.Q. Terceiro Setor, Economia Social e Economia Solidária: Laboratório Por Excelência de Inovação Social. Sociologia 2017, 1, 100-121. Available online: https:/ / hdl.handle.net/10216/108522 (accessed on 5 November 2021).

13. Burger, R.; Owens, T. Promoting Transparency in the NGO Sector: Examining the Availability and Reliability of Self-Reported Data. World Dev. 2010, 38, 1263-1277. Available online: https:/ / www.econstor.eu/obitstream/10419/65448/1/595031048.pdf (accessed on 3 July 2021). [CrossRef]

14. Rodríguez, M.D.M.G.; Pérez, M.D.C.C.; Godoy, M.L. Determining Factors in Online Transparency of NGOs: A Spanish Case Study. Volunt. Int. J. Volunt. Nonprofit Organ. 2011, 23, 661-683. [CrossRef]

15. Striebing, C. Professionalization and Voluntary Transparency Practices in Nonprofit Organizations. Nonprofit Manag. Leadersh. 2017, 28, 65-83. [CrossRef]

16. Cabedo, J.D.; Fuertes-Fuertes, I.; Maset-LLaudes, A.; Tirado-Beltrán, J.M. Improving and measuring transparency in NGOs: A disclosure index for activities and projects. Nonprofit Manag. Leadersh. 2018, 28, 329-348. [CrossRef]

17. Dumont, G.E. Transparency or accountability? The purpose of online technologies for nonprofits. Int. Rev. Public Adm. 2013, 18, 7-29. [CrossRef]

18. Hyndman, N.; McConville, D. Transparency in reporting on charities' efficiency: A framework for analysis. Nonprofit Volunt. Sect. Q. 2016, 45, 844-865. [CrossRef]

19. Sanzo-Pérez, M.J.; Rey-Garcia, M.; Álvarez-González, L.I. The Drivers of Voluntary Transparency in Nonprofits: Professionalization and Partnerships with Firms as Determinants. Volunt. Int. J. Volunt. Nonprofit Organ. 2017, 28, 1595-1621. [CrossRef]

20. Carvalho, A. O Enquadramento Contabilístico das Entidades Sem Fins Lucrativos-Um Ensaio. Ph.D. Thesis, Universidade do Minho, Braga, Portugal, 2007. Available online: http://hdl.handle.net/1822/7223 (accessed on 3 July 2021).

21. Moreno-Albarracín, A.L.; Licerán-Gutierrez, A.; Ortega-Rodríguez, C.; Labella, Á.; Rodríguez, R.M. Measuring What Is Not SeenTransparency and Good Governance Nonprofit Indicators to Overcome the Limitations of Accounting Models. Sustainability 2020, 12, 7275. [CrossRef]

22. Salamon, L.M.; Sokolowski, S.W. Beyond Nonprofits: Re-conceptualizing the Third Sector. Volunt. Int. J. Volunt. Nonprofit Organ. 2016, 27, 1515-1545. [CrossRef]

23. Gomes, J.M.L.; Pires, J.M.R. Normalização Contabilística Para Entidades do Setor Não Lucrativo; Vida Económica Editorial: Porto, Portugal, 2014; ISBN 978-972-788-932-7.

24. Andrade, A.M.; Franco, R.C. Economia do Conhecimento e Organizações Sem Fins Lucrativos, 1st ed.; Princípia Editora, Lda.: Parede, Portugal, 2007; ISBN 978-972-8589-79-0.

25. Domingues, M.I.C. O Tratamento Contabilístico e Fiscal das Fundações sem Fins Lucrativos em Portugal. Ph.D. Thesis, Instituto Superior de Contabilidade e Administração de Coimbra, Coimbra, Portugal, 2016. Available online: https://comum.rcaap.pt/ handle/10400.26/17534 (accessed on 26 May 2021).

26. Meira, D.A. O Regime Económico das Cooperativas no Direito Português: O Capital Social; Grupo Editorial Vida Ecónomica: Porto, Portugal, 2009.

27. Teixeira, Z.M.F. O Relato Financeiro nas IPSS: Estudo de Caso de uma IPSS do Concelho de Vila Nova de Gaia. Ph.D. Thesis, Instituto Politécnico do Porto, Porto, Portugal, 2014.

28. Tremblay-Boire, J.; Prakash, A. Accountability. org: Online disclosures by US nonprofits. Volunt. Int. J. Volunt. Nonprofit Organ. 2015, 26, 693-719. [CrossRef]

29. Teasdale, S. What's in a Name? Making Sense of Social Enterprise Discourses. Public Policy Adm. 2012, 27, 99-119. [CrossRef]

30. Yunus, M.; Biggeri, M.; Testi, E. Social Economy and Social Business Supporting Policies for Sustainable Human Development in a Post-COVID-19 World. Sustainability 2021, 13, 12155. [CrossRef]

31. Armstrong, E. Integrity, Transparency and Accountability in Public Administration: Recent Trends, Regional and International Developments and Emerging Issues; United Nations, Department of Economic and Social Affairs: New York, NY, USA, 2005; pp. 1-10.

32. Fox, J. The uncertain relationship between transparency and accountability. Dev. Pr. 2007, 17, 663-671. [CrossRef]

33. Lee, R.L.; Joseph, R.C. An examination of web disclosure and organizational transparency. Comput. Hum. Behav. 2013, 29, 2218-2224. [CrossRef] 
34. Saxton, G.D.; Guo, C. Accountability Online: Understanding the Web-Based Accountability Practices of Nonprofit Organizations. Nonprofit Volunt. Sect. Q. 2011, 40, 270-295. [CrossRef]

35. Hale, K. Understanding nonprofit transparency: The limits of formal regulation in the American nonprofit sector. Int. Rev. Public Adm. 2013, 18, 31-49. [CrossRef]

36. Moreno-Albarracín, A.L.; Ortega-Rodríguez, C.; Licerán-Gutiérrez, A.; Labella, Á.; Martínez, L. Transparency indicators to improve accountability for non-profit organizations: A Spanish case study. Technol. Econ. Dev. Econ. 2021, 27, 763-782. [CrossRef]

37. Behn, B.K.; DeVries, D.D.; Lin, J. The determinants of transparency in nonprofit organizations: An exploratory study. Adv. Account. 2010, 26, 6-12. [CrossRef]

38. Baur, D.; Schmitz, H.P. Corporations and NGOs: When accountability leads to co-optation. J. Bus. Ethics 2012, 106, 9-21. [CrossRef]

39. Decree-Law No. 172-A/2014 of 14 November. Available online: https://dre.pt/dre/legislacao-consolidada/decreto-lei/2014-6 9878914 (accessed on 15 December 2021).

40. Ferreira, A.; Marques, R.P.; Santos, C.; Mendes, H.; Azevedo, G. Evaluation of the Online Accountability of the Portuguese Private Institutions of Social Solidarity. In Modernization and Accountability in the Social Economy Sector; IGI-Global: Aveiro, Portugal, 2019. [CrossRef]

41. Pardal, P.; Carreira, F.; Alexandre, P. O grau de divulgação de informação nos websites das IPSS. In Proceedings of the VII Congresso Internacional de Contabilidade e Auditoria (XVII CICA), Porto, Portugal, 7-8 November 2019.

42. Tomé, B.; Meira, D.; Bandeira, A. Integrated reporting and corporate social responsibility in the context of social economy (Mutual associations in the health and welfare sector). CIRIEC-España Rev. Econ. Publica Soc. Coop. 2015, 85, 109-142. [CrossRef]

43. Silva, L.; Pereira, L.; Lopes, C. A transparência na prestação de informação de âmbito contabilístico e fiscal das entidades sem fins lucrativos: Estudo de caso. In Proceedings of the XIX Seminário Luso-Espanhol (SLE) de Economia Empresarial, Algarve, Portugal, 9-10 November 2017.

44. Ortega-Rodríguez, C.; Licerán-Gutiérrez, A.; Moreno-Albarracín, A.L. Transparency as a key element in accountability in non-profit organizations: A systematic literature review. Sustainability 2020, 12, 5834. [CrossRef]

45. Augusto, A. Metodologias quantitativas/metodologias qualitativas: Mais do que uma questão de preferência. In Forum Sociológico; Série II; CESNOVA: Lisboa, Portugal, 2014; pp. 73-77. [CrossRef]

46. Tomé, B.; Bandeira, A.; Meira, D. Os desafios das Cooperativas de Solidariedade Social Portuguesas face ao Novo Estatuto das Instituições Particulares De Solidariedade Social. In Proceedings of the XVI Congreso de Investigadores en Economía Social y Cooperativa, Valencia, Spain, 19-21 October 2016. 